\begin{tabular}{|l|l|l||}
\hline \multicolumn{2}{|c|}{ PublisherInfo } \\
\hline \hline PublisherName & $:$ & BioMed Central \\
\hline \hline PublisherLocation & $:$ & London \\
\hline \hline PublisherImprintName & $:$ & BioMed Central \\
\hline \hline
\end{tabular}

\title{
Risk factors for ventilator associated pneumonia
}

\begin{tabular}{||l|l|l||}
\hline \multicolumn{2}{|c||}{ ArticleInfo } \\
\hline \hline ArticleID & $:$ & 4259 \\
\hline \hline ArticleDOI & $:$ & $10.1186 /$ ccf-2000-6640 \\
\hline \hline ArticleCitationID & $:$ & 6640 \\
\hline \hline ArticleSequenceNumber & $:$ & 47 \\
\hline \hline ArticleCategory & $:$ & Paper Report \\
\hline \hline ArticleFirstPage & $:$ & 1 \\
\hline \hline ArticleLastPage & $:$ & 3 \\
\hline \hline & $:$ & RegistrationDate : 2000-10-12 \\
ArticleHistory & $:$ & OnlineDate \\
\hline \hline ArticleCopyright & $:$ & Current Science Ltd2000-10-12 \\
\hline \hline ArticleGrants & $:$ & \\
\hline \hline ArticleContext & $:$ & 1305433 \\
\hline \hline
\end{tabular}


Aff1 Southampton General Hospital, UK

\section{Keywords}

Anesthesia, antibiotic resistance, infection, intensive care, nosocomial

\section{Comments}

Nosocomial infections, in particular ventilator associated pneumonia (VAP), are a major cause of increased length of stay in the intensive care unit (ICU) and are associated with increased morbidity and mortality. This study attempted to identify risk factors for the development of VAP. Interestingly, the incidence of VAP was found to be higher in patients who had not received antibiotics during the first 48 $\mathrm{h}$ of admission to the ICU. There may be two explanations for this. Firstly, large number of patients were admitted following surgery ( $47 \%)$. These patients may be expected to be fitter than emergency admissions and receive postoperative antibiotics. This would lead to an increased number of patients with thoracic trauma or aspiration (ie emergencies at higher risk of VAP) in the group not receiving routine antibiotics. Secondly, those who advocate the practice of routine selective decontamination would argue that antibiotics in the first $48 \mathrm{~h}$ reduce the risk of nosocomial infections, especially VAP. The authors make the point that patients with thoracic trauma, aspiration, head trauma or who have undergone emergency intubation are at significantly higher risk of developing VAP and hence should be rigorously observed. Given their findings, perhaps the role of prophylactic antibiotics in these patients should be re-examined. Unfortunately the authors make no comment as to whether the patients were intubated nasally or orally, whether closed suction was used or how many patients were enterally fed.

\section{Introduction}

This prospective study collected data to evaluate factors associated with the onset of VAP in ICU patients.

\section{Methods}


- Patients $(n=486)$ were initially treated with $100 \%$ oxygen and muscle relaxants. Oxygen was then reduced according to the clinical condition of the patient

- A heat moisture exchanger was used and changed daily, the ventilator circuit was changed weekly

- A total of 260 patients underwent ventilation for $48 \mathrm{~h}$ or greater and were included in the analysis

- Patients received ranitidine and sulcralfate as stress ulcer prophylaxis. Selective decontamination of the digestive tract was not used

- Potential risk factors for VAP were recorded on admission

- VAP was diagnosed on the basis of a new or persistent opacity seen on chest radiographs and any two of the following: purulent endotracheal secretions, core temperature greater than $38^{\circ} \mathrm{C}$ or less than $36^{\circ} \mathrm{C}$, leukocyte count greater than 10,000 or less than 4000 cells $/ \mathrm{mm}^{3}$ and exudative pleural effusions

- Sputum cultures were performed on all patients with pneumonia. Samples were obtained by endotracheal suction.

- Data were subdivided according to bacteriology into four groups, ie Pseudomonas aeruginosa, Acinetobacter baumanii, methicillin resistant staphylococci (MRSA) and others

\section{Results}

Of the 260 patients analysed, $47 \%$ were admitted postoperatively, $31 \%$ were medical and $22 \%$ were trauma patients. Eighty-one patients had 99 episodes of VAP. Pseudomonas aeruginosa was the causal organism in 33\% patients, 17 episodes were caused by MRSA, nine by Acinetobacter sp and 40 episodes were caused by non-resistant species. The period of ventilation, the incidence of acute respiratory distress syndrome and the incidence of sepsis were significantly higher in patients with VAP. A smaller number (44\% versus 57\%) of patients with VAP had been administered antibiotics during the first $48 \mathrm{~h}$ compared with those without pneumonia. Of the patients with VAP, 33\% had thorax trauma versus 7\% in the patients without VAP $(P<0.001)$. Other significant risk factors for VAP included emergency intubation (cardiac or respiratory arrest or decreased conscious level), aspiration and a Glasgow coma scale of nine or less.

\section{References}

1. Akca O, Koltka K, Uzel S, Cakar N, Pembeci K, Sayan M, Tutuncu A, Karakas S, Calangu S, Ozkan T, Esen F, Telci L, Sessler D, Akpir K: Risk factors for early-onset, ventilator associated pneumonia in critical care patients. Anesthesiology. 2000, 93: 638-645. 